\title{
Director's perspectives on the meaning and dimensions of corporate reputation
}

\author{
C. Reddiar and N. Kleyn \\ Gordon Institute of Business Science, PO Box 787602, \\ University of Pretoria, Republic of South Africa \\ kleynn@gibs.co.za \\ R. Abratt ${ }^{*}$ \\ University of the Witwatersrand and, \\ Nova Southeastern University, 3301 College Avenue, \\ Fort Lauderdale, FI 33327 \\ Abratt@nova.edu \\ Received June 2011
}

\begin{abstract}
The purpose of this research is to explore the perspectives of directors to determine how they define, perceive, value, build and manage corporate reputation. A qualitative research design was employed. In order to gauge director's perspectives, 12 semi-structured, in-depth interviews were conducted with the directors of a multi-national company based in South Africa. The company operates in a highly regulated and competitive industry. The findings demonstrate that corporate reputation is indeed acknowledged as a key, intangible asset. Whilst the directors did not possess clear insight into building and managing corporate reputation, several key themes emerged. We report on their perceptions of the definitions, key dimensions and value ascribed to corporate reputation. By demonstrating the value that is associated with corporate reputation and by ascertaining that directors are indeed the appropriate custodians of corporate reputation, there will be better acceptance in introducing corporate reputation as a board room agenda item, that is well understood and implemented.
\end{abstract}

*To whom all correspondence should be addressed.

\section{Introduction}

Corporate reputation is increasingly regarded as a highly valued, intangible asset that is difficult to imitate and accordingly may provide a sustainable competitive advantage. Corporate reputation has evolved into a market mechanism that constrains the actions of corporations and ensures socially acceptable outcomes (O'Callaghan, 2007). In an increasingly globalised world that is fraught with corporate malfeasance, corporate reputation has been elevated to the domain of the board room as a strategic imperative.

In South Africa, the King III report (IOD, 2009) has specifically mandated the directors of a company to take formal responsibility for corporate reputation at board level by specifying corporate reputation as a board agenda item. Whilst the King III Report (IOD, 2009) is not legislation, it is a binding code for all public companies listed on the Johannesburg Stock Exchange and indeed is intended to apply to all corporate entities in South Africa. So whilst not statutory in nature, the King III Report (IOD, 2009) obliges public companies to apply or explain its adherence to the principles. It is submitted, that as the appointed custodians of corporate reputation, directors of publicly listed companies will be hard pressed to provide an explanation for not embracing the concept of corporate reputation. In order to consider corporate reputation as mandated by the King III Report (IOD, 2009), directors must fully comprehend the dimensions of corporate reputation and the benefits that can be attributed to this construct in order to comply with the spirit and not merely the letter of the King III Report. Kana (2009: 1) enunciates the spirit upon which the King III Report is based in that, "a code of principles can only ever be as good as one's ability to put it into practice."

The purpose of this research is to explore the perspectives of executive directors regarding their understanding of how corporate reputation is defined; the dimensions of corporate reputation; the value attributed to corporate reputation; their responsibilities as custodians of corporate reputation; and the manner in which they believe they should build and manage corporate reputation

\section{Literature review}

The literature consists of a review of the definition of corporate reputation, the dimensions of corporate reputation, the value of corporate reputation, and the role of directors in relation to reputation and building a corporate reputation. 
The areas of uncertainly within this domain were articulated in the recent work of Walker (2010) wherein a systematic review of the corporate reputation literature review showed that three fundamental problems persisted in the literature. These related to the requirement for a comprehensive and accepted definition; the difficulty in actually operationalising the construct and the further need for developing the theory base (Walker, 2010).

\section{Defining corporate reputation}

The problem of providing a single definition of corporate reputation permeates through various ancillary studies in the corporate reputation domain. It is evidenced by more recent calls for one single voice and a single vision in defining corporate reputation as a construct (Barnett, Boyle \& Gardberg, 2000); to rectify the deficiencies in the definitions of corporate reputation (Wartick, 2002); and to obtain clarity with regards to the construct in order to build on existing theory (Mahon, 2002). The call for an acceptable definition was reinforced by Lewellyn (2002) who stated that even though the field of corporate reputation had rapidly developed, much remained to be done to focus the proliferation of theory in the area of corporate reputation.

As a result of the lack of a dedicated focus and the proliferation of definitions, Barnett, Jermier and Lafferty (2006) took up the call for clarity and reviewed the relevant corporate reputation literature. They perused 49 of the more acceptable definitions of corporate reputation, in order to answer the fundamental question that remained unsettled in the academic literature namely, what is corporate reputation?

The review of the literature and a consolidation of the findings in this regard suggests that corporate reputation can be defined as, "The sum of the perceptions of a corporation's past actions; current performance; and future prospects that results from the corporation's ability to deliver valued outcomes to multiple stakeholders and gauges a corporation's relative standing both internally with employees and externally with its stakeholders, in both its competitive and institutional environments" (adapted from Fombrun and Rindova (1996), Wiedmann and Buxel (2005) and Walker (2010). Simply stated, a company's corporate reputation is the sum of what the company is seen to be (Whetten \& Mackey, 2002).

Our first research question is therefore:

How do you define Corporate Reputation?

\section{Determining the dimensions of corporate reputation}

The literature acknowledged that identifying and leveraging the dimensions of corporate reputation could be of invaluable importance to companies (Gabbioneta, Ravasi, \& Mazzola, 2007). A review of relevant studies indicated that a range of approaches had been used to determine the dimensions of corporate reputation. Walker (2010) stated that reputation consisted of different dimensions and that these dimensions were issue specific for each stakeholder and/or company. This supported O'Callaghan's (2007) contention that a one size fits all approach to corporate reputation was not adequate. The dimensions that constitute the portfolio of corporate reputation were varied and addressed the fundamental components of a company conducting its business in its jurisdiction. The dimensions each contributed to the overall reputation of the company and each dimension was significant in terms of the literature. (see amongst others, Gabbioneta et al., 2007; Fombrun and Van Reil 2004; Mercer 2004; Gardberg and Fombrun 2006; Carter 2006; Fombrun 2007; Petkova, Rindova and Gupta, 2008 and Kim, Bach and Clelland, 2007).

Our second research question is:

What are the dimensions required in order to build and manage corporate reputation?

\section{Determining the value of corporate reputation}

"Reputation is arguably the single most valued organisational asset,"

Gibson, Gonzales and Castanon (2006:15). Firms that value their reputation need to maintain a continued focus on the management of this important corporate asset. Fang (2005) postulated that reputation enabled a company to earn economic rents, which in turn incentivised the firms to reinvest in building and maintaining their reputations. The benefits of a good corporate reputation are accordingly of great value to a corporate in addition to providing the firm with a licence with which to operate (Pruzan, 2001). In addition, Firestein (2006) asserted that a firm's reputation remained the strongest signal to the market regarding the firm's sustainability.

Hall (1993) identified reputation as people dependant and his early findings indicated that reputation triumphed as the firm's key intangible resource and accordingly it was vital for firms to develop an understanding of the manner in which this resource was accumulated. Ang and Wight (2009) noted in support that as this intangible resource was unobservable and therefore difficult to imitate and quantify, the accumulation of a corporate reputation created value for the company in the form of a sustainable competitive advantage over less reputable peers.

Galliard and Louisot (2006) confirmed in their findings that even though corporate reputation was an intangible asset and did not have an accounting value assigned to it; corporate reputation remained one of the company's most valuable assets. Galliard and Louisot (2006) noted that a company that built a sound corporate reputation was able to: build stakeholder trust and confidence; maintain a social licence to operate; attract investments; boost both customer and its supplier loyalty; reduce regulatory intervention; create barriers to entry; facilitate premium pricing; recruit and retain the best employees; and harness a store of reputational capital that protects against future crisis. Our third research question is:

What is the value attributed to a good corporate reputation? 


\section{The role of directors in building and managing corporate reputation}

The board of directors are tasked with accountability to shareholders for all aspects of the business (Roberts, McNulty \& Stiles, 2005). Dowling (2006) argued that corporate reputation management was primarily; first and foremost, the responsibility of the board of directors and directors that did not deal with reputation management placed their companies at risk and continued to do so until such time as this corporate asset was elevated to board level. Boards are ultimately responsible for corporate performance under conditions of increased shareholder activism and media scrutiny (Kiel, Nicholson \& Barclay, 2005). If, as advocated by O'Callaghan (2007), activists and advocates were to fight the activism debate on the terrain of corporate reputation, board accountability for corporate reputation, irrespective of jurisdiction, would be inevitable. Despite the importance of reputation, Dowling (2006) found that the concept of corporate reputation seldom appeared on board papers as an agenda item.

South African boards are of a unitary structure and are similar to those in the United Kingdom and accordingly are comprised of executive and non-executive directors. Roberts et al. (2005) found that trust levels between executive and non-executive directors were crucial to ensure a well functioning board and that non-executives who are removed from the day to day operations of the business must be informed of the risks posed to the company by executive directors. In addition to the important role played by nonexecutive directors, board effectiveness has been found to be dependent upon a number of factors which included the director's experience, the skills they possessed and the judgments exercised by each executive and non-executive director, which combined to determine the effectiveness of the board (Roberts et al., 2005).

It is submitted that whilst every member of the company is responsible for maintaining the company's reputation, it is the ultimate duty of the board of directors together with the chief executive officer of the company, to develop and build corporate reputation. This view is supported by Wiedmann and Buxel (2005) who stated that the achievement of the company's reputational objectives was the direct responsibility of the company's executive board and management, which supported the calls of academics such as Davies, Chun and Da Silva (2001) and Fombrun (1996), in that corporate reputation must fall within the domain of boards of directors. Jagt (2005) noted that reputation management posed one of the major balancing acts in an executive's leadership role as directors were required to perpetually balance the interests of multiple stakeholders at the same time. Although it is the board of directors who are ultimately accountable for corporate reputation, individual directors should be able to voice their concerns and ask the difficult questions that must be asked for the benefit of the company (Zandstra, 2002).

Our next research question therefore is:

What is your role as director in building and managing corporate reputation?

\section{Building and managing corporate reputation}

"Building and maintaining a reputation, takes careful thought, meticulous planning and constant work over years. And it can be lost overnight (Larkin, 2003). Hall (1993) recommended that management should constantly manage and take heed of corporate reputation. This approach goes beyond conducting an occasional review of reputational risks facing the company and includes constant monitoring of the surrounding environment. O'Callaghan (2007) surmised that two factors had changed the management of corporate reputation, namely the diverse jurisdictions that companies now operated in due to the phenomenon of globalisation, and the increasing importance attributed to viewing reputations as a valuable asset that could form the basis of competitive advantage.

O'Callaghan (2007) noted that not only did corporate reputation need to be built and managed, but that an organisation's corporate reputation also required protection against damage. One of the biggest challenges posed to maintaining and enhancing corporate reputation was that most directors and senior management did not know how to define, measure, or manage corporate reputation (Alsop, 2004). If one cannot define, or measure, or manage an integral asset of the company, there is much cause for concern.

Fombrun and Van Riel (2004) advocated for the active management of corporate reputations in order to derive maximum competitive advantage and to ensure that additional value was created for the company. This was echoed in the recent findings of Puncheva-Michelotti and Michelotti (2010: 249-250), which demonstrated that in order to leverage off the substantial benefits that are a consequence of a good corporate reputation, companies must build corporate reputations, "in ways that contribute to their ability to attract customers, employees, investors and the support of local communities."

Corporate reputation must be built and managed proactively and the findings of Mackenzie (2007) indicated that companies have realised that non-compliance with socially responsible standards, constituted a risk to their reputations across all significant stakeholders. Wiedmann (2002) stated that integrative and long term concepts should be put into place within the framework of an integrative and purposeful reputation management plan and that the management of corporate reputation spanned across all areas of the business including finance; people; resourcing; distribution; and production.

Firestein (2006:25) proffered some advice that, "a company's approach must include structured engagement with investors, regulators, activist organisations, communities and the media." As most company information was collected by stakeholders via the media, it was acknowledged that management of the media was an important aspect of reputation management (Carroll, 2004). Coombs (2007) incorporated new forms of media, together with the traditional communication channels and included the internet, weblogs and blogs, as an additional important source of reputational management. By contrast Kim et al. 
(2007) found that a positive reputation in the media did not necessarily translate into additional corporate profitability. Stakeholders consist of any group of people that can affect or in turn be affected by the actions of an organisation (Bryson, 2004). Coombs (2007) noted that reputations were integrally comprised of the stakeholder's evaluation of the manner in which the organisation met stakeholder's expectations. In turn, Reichart (2003) introduced the concept of the stakeholder expectation gap, which was, he argued, the source of problems for most organisations. He concluded that no matter the investment in corporate reputation, the strategy would fall short, if stakeholder's expectations of the firm fell short of the corporate reputation that the firm wanted to project.

Petkova et al. (2008) demonstrated, that in the case of newly founded firms, the accumulation of reputation occurred by using symbolic activities; investing in both human and social capital; ensuring quality products and building close relationships with customers. The success at building corporate reputation was often assessed by upward moves in reputation rankings (Fombrun, 2007). Wiedmann and Buxel (2005) sounded the call for a more comprehensive analysis and investigation into the development and formalising of corporate reputation management in both the theoretical and practical domains. Puncheva-Machelotti and Machelotti (2010) further advocated that the management of corporate reputation included the establishment of suitable reputation measures although the authors noted that reputational measures had been the subject of much criticism as such measures had historically measured the perceptions of stakeholders rather the construct of corporate reputation itself. As a consequence much subjectivity prevailed and did not add clarity to the aims of distilling management requirements.

Our last research question is: How do you as director build and manage corporate
reputation?

\section{Methodology}

A qualitative research design was employed. Face to face interviews were conducted with the target population of executive directors in order to ascertain their perceptions and experiences in relation to their own understanding of the construct of corporate reputation; the dimensions and value of corporate reputation; and the management of such dimensions in order to build corporate reputation. The methodology was similar to the approaches adopted by early researchers in the field of corporate reputation (Fombrun, 1996) and more recent researchers who were still attempting to ascertain the answers to these fundamental questions within the field of corporate reputation (Hillenbrand \& Money, 2007). The target firm selected was a multi-national company that is listed on the Johannesburg Stock Exchange. It operates in a highly competitive and specialised industry which is highly regulated.

A purposive sampling was utilised. The target firm employs 14 executive directors. All 14 directors were to be interviewed but two of the directors were travelling out of the country at the time that the interviews were conducted. Accordingly the number of respondents in this study was 12 out of the 14 directors of the target firm. The interviews ranged between 40 minutes to 90 minutes. All of the interviews, except for one, were recorded by use of a dictaphone after receiving the consent of each interviewee. The one director did not seem completely at ease with the suggestion of recording the interview and accordingly hand written notes were taken as it was agreed not to record the interview.

A list of prompting questions was prepared in the form of an interview guide. Questions were open ended. As an additional precaution an interview matrix was designed, which ensured that the probing questions listed on the interview guide, were linked to each of the research questions and accordingly facilitated the required data gathering.

The data compiled from the interviews were analysed in accordance with the inductive process and systematic stages outlined by Miles and Huberman (1994), as further expanded by Hillenbrand and Money (2007:286), which comprise mainly of the, "preparation of written up field notes; qualitative clustering to identify trends in the data and the further analysis to identify high level themes and links between clusters." Hillenbrand and Money (2007) stated that the ability to cluster the data enhanced the understanding of the data, by grouping the data in terms of its similarity or evident patterns that may emerge, which in turn leads to the identification of the high level themes.

\section{Results}

\section{Demographics}

All 12 interviewees are executive directors and are responsible for the executive management functions of a publicly listed company in South Africa. Seven were aged between $40-49$ and 5 were between 50 and 59. Only one was female. Of the 12 directors interviewed, four of the directors are considered as "operational" directors, meaning that they are directly in control of operations and revenue generating business functions. The remaining eight directors are considered to be in support services which operate predominately as cost centres and which are required to support the operational functions of the business. Support services include the directors of: legal services; compliance; corporate finance; new business development; human resources; internal audit; product development; and the chief financial officer.

\section{A director's definition of corporate reputation}

Corporate reputation meant different things to the different respondents. In order to clarify a precise understanding of the terms, the interviewees were requested to compose their own definition of corporate reputation. The majority of the interviewees voiced their apprehension of attempting to define a term, which in their minds was quite broad, however several others were quite confident in defining what they believed corporate reputation to be. The definitions have been listed below: 
"Corporate reputation is the ethics you live by, the brand you create for yourself, how you operate, treat your stakeholders, how you conduct yourself and how you conduct business".

"It's all about your behaviour, the perceptions that form from your behaviour, how you conduct yourself, you know the moral fibre, your code, your ethics."

"The perceptions that stakeholders have of the company and how it performs its business and the type of business it operates in".

"The standing of the company in the eyes of the public or society and the ambit of stakeholders, where the company mostly conducts its business".

"A combination of factors which entails the brand, established through the media and through people's perceptions together with pre-existing reputation and experience as a customer together with the level of integrity, honesty and empathy displayed in our manner of engagement"

"To be judged by our shareholders and peers, based on decisions made which affect business outcomes"

It is the way that market treats and sees the company, whether it's a reputable company and a company they want to deal with"

A strong link to reputation was made via the brand connotation and many of the respondents expressed the sentiment that brand and reputation were inextricably intertwined. Accordingly, many interviewees stated that by driving the brand of the company, the company was driving its corporate reputation extensively. Whilst many of the directors, when asked whether the company image and/or identity equated to the company's reputation, were able to distinguish a difference but there was confusion expressed. The ambiguity within the realms of distinguishing corporate identity; corporate image and corporate reputation was expressed by two of the interviewees as follows:

"We talk loose and fast, about protection of the company's image. What is protection of image other than reputation? It is no different. The image is out there, it is all about brand and I think we need to find the tentacles that suck it all together"

"Reputation, identity and image of the company, I think it's so interchangeable, they are just so directly linked. I don't know how one would say the identity is different from the image of the company; it's different to the reputation - for me they are just so intertwined."

It is apparent that whilst the concept of brand can be clearly distinguished from corporate reputation, much ambiguity remains between the concepts of identity and image when related to reputation. This may prove to be an academic distinction in the minds of directors, as the findings demonstrated that reputation is the overall arching concept under which identity and image reside.

\section{Dimensions of corporate reputation}

Data was gathered in arriving at the basket of dimensions of corporate reputation and the interviewees were enthused to provide the dimensions that they believed were to be the focus of any corporate reputation management strategy. As stated by one of the respondents':

"So maybe as part of a board you say we've now got to look at reputation, you will look at the building blocks of what makes a good reputation and possibly, in fact I'd submit probably you would without that form or structure, you probably would have missed something".

The dimensions mentioned in the interviews are illustrated in Figure 1, and have been clustered into themes. The themes that became evident during the interviews pertained to corporate conduct; leadership; customers; financial performance; corporate governance and crisis management.

Directors have many different perceptions of the dimensions that comprise corporate reputation. In order to analyse the results pertaining to the dimensions of corporate reputation the findings depicted in Figure 1 are dis-aggregated further to categorise the main dimensions.

\section{Corporate conduct as a dimension of corporate reputation}

Most of the respondent's referenced corporate conduct and referred to as: based on a set of values; code of conduct; code of ethics or based on the corporate culture as the truest indicator of a corporation's reputation. This was addressed in various forms including the corporate ethos, fair dealings, company promises, and being consistent.

As indicated by one director:

"It all comes down to the moral fibre of the company: how do you do things; how do you want to do things; what are your values; do you live up to your values. Now those types of things you can manage, you have codes; you can have a value set, you can have an expected behavioural set."

Another interviewee simply put that corporate reputation is an output of an organisation's behaviour, whilst yet another commented that company conduct is an integral indicator of whether or not the company delivers on its promises. Consistency and fairness was often cited by interviewees when referencing the type of corporate conduct that is expected to be associated with a good corporate reputation and fundamentally at the heart of this conduct was the values and ethics of the organisation. This could be identified by the corporate culture and the behaviour of the people within the organisation. 


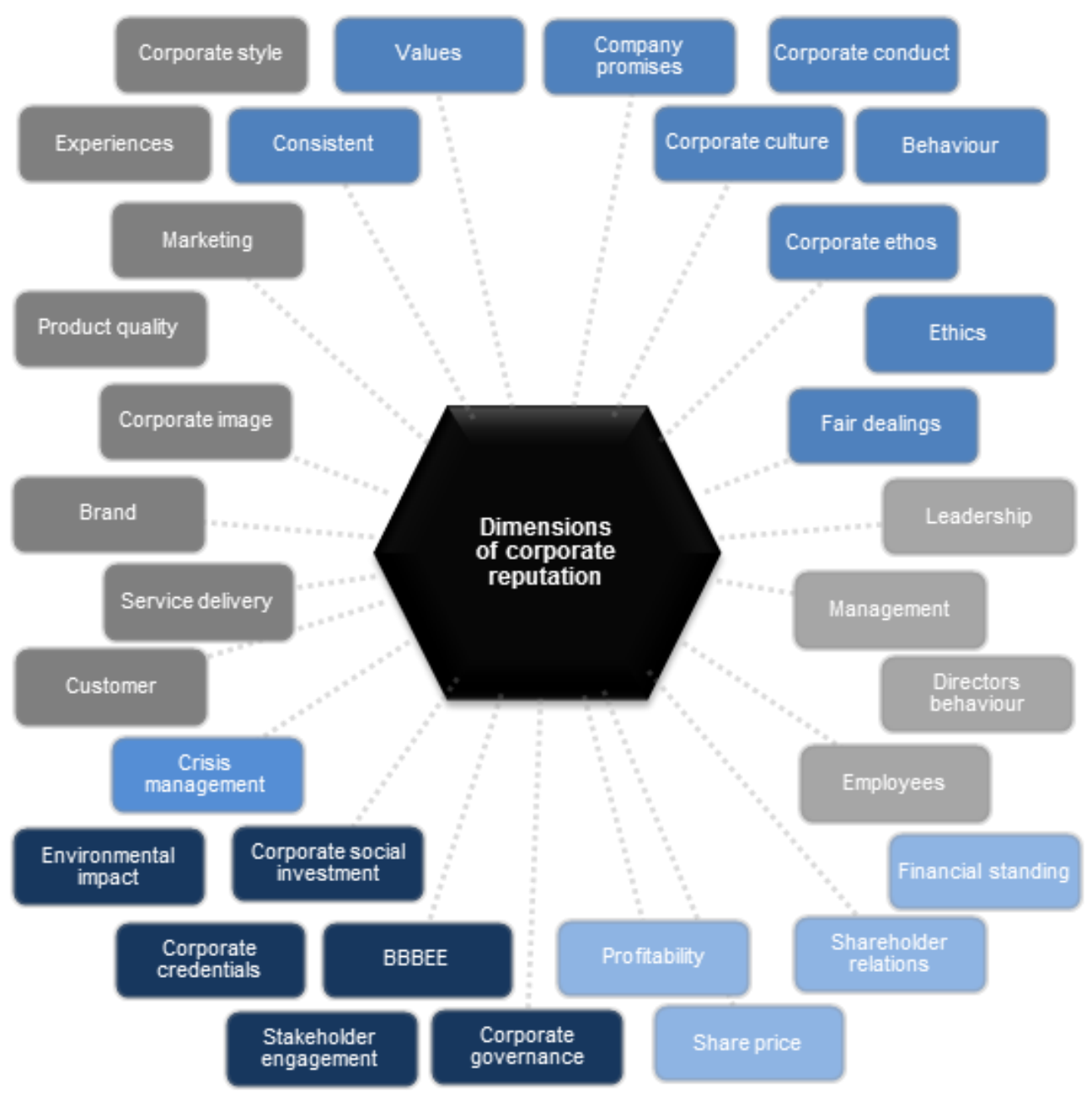

Figure1: Dimensions of corporate reputation

\section{Leadership as a dimension of corporate reputation}

The most cited dimension of corporate reputation was the company's leadership and its people. This was mentioned by all respondents in various categories, be it leadership, management, or employees of the company. The directors of the company unequivocally in all instances stated that the main determinant of the corporate reputation rested on the foundation of the company's leadership and its people.

Some interviewee's opinions indicated that this was the reason why the management of corporate reputation was so perplexing as the company's reputation could be marred by the act of a single individual. It was of concern to the interviewees that a hard built reputation can be tarnished if not destroyed over one particular incident. As stated by one of the directors:

"Reputation needs to be earned, can't be bought, can be destroyed quite quickly and if there are problems it needs to be managed effectively."

Another director commented as follows:

"Each action of an individual that carries the power to make decisions that affect a corporation must bear in mind the reputation that is going to follow."
Directors were cognisant of the role that people (including themselves) played in building corporate reputation. One director remarked that:

"The caretakers of that (corporate) reputation are the executive directors and executive management because they are the ones actually engaging the stakeholders. So the board needs to manage how they conduct business, live up to the values of the business."

Interestingly only one of the interviewees categorised service providers of the company to sit within this realm. The interviewee noted that in the services industry, outsourced service providers were often the front of the company that many customers were facing.

\section{Customer engagement as a dimension of corporate reputation}

Interviewees' discussions clearly indicated that without adequate customer engagement there would not be a business and accordingly corporate reputation would be of little help, if the focus and drive on product and service delivery together with the brand promise was unfulfilled. 
One of the interviewees stated that value for money irrespective of quality and service delivery may outshine reputation as a precursor for deciding whether the customer will elect to do business with a company with a less reputable corporation. This could be explained by a fellow interviewee's comments that:

"If you've got a good long term reputation you can get away with mistakes and people accept it's not in your nature. But whereas if you continue doing them and not acknowledging them you damage your reputation in the long term."

This view was supported by many of the interviewees, and expressed such as the comment that follows:

"I have no doubt, that if I had a previous good experience with company $x$ and on a given occasion there is bad service delivery, I would take the time to find out why. There would be more compassion, whereas with a new entrant, I would just not bother to go back."

\section{Financial performance as a dimension of corporate reputation}

Whilst financial performance of the company was cited by many of the interviewees, it was not cited by all. Those that did cite financial performance as a dimension were vocal that financial performance significantly determined the company's reputation and were mainly directors in the support services category. The interviewees stated that investors were the most active of all the company's stakeholders in the South African context and accordingly, the financial performance of the company was a key element.

Most directors emphasised though that long term financial performance was the measure in question and it no longer sufficed to deliver on short term financial goals to win the confidence of investors. Some of the interviewees responded that by enhancing the share price of the company, one influenced the reputation of the company. Others volunteered that the share price was an indicator of the market's signal on the reputation of the company. By contrast one of the interviewee's expressed his view that:

"The blip in the share price is not a measure of the wide spread perception of your reputation, it's driven by speculators."

Profitability for other interviewees was key and again the point was made in the interviews that a strong reputation will not salvage a company that has not turned a profit for some time.

\section{Corporate governance as a dimension of corporate reputation}

Many of the interviewees acknowledged that good corporate governance was a pivotal dimension of corporate reputation. The far reaching emphasis of governance was indicated by the many detailed comments regarding stakeholder engagement; transactions that could potentially give rise to environmental concerns and in general the company's corporate social investment programs. It was their opinion that the company could significantly enhance its reputation, particularly with those stakeholders that it did not interact with directly, by investing in local communities and supporting programs such as enterprise development.

One of the interviewee's also included broad based black empowerment as a dimension of the company's reputation. He submitted that in the context of the South African environment, the uniqueness of black empowerment obligations on corporate South Africa were instrumental in shaping the perception of the company' reputation. Another interviewee alluded to the necessity of possessing the right corporate credentials in South Africa, in order to ensure a level playing field and in this regard, referenced the ability to participate in government tenders or even at a basic level to meet the legislative requirements relating to qualifying for such tenders. This was again a reference to ensuring that the company's black empowerment rating is in order.

\section{Crisis management plan as a dimension of corporate reputation}

One of the interviewees was particularly vocal that a crisis management plan had to form a dimension of corporate reputation. Whilst crisis management was referenced by a few other interviewees, it was not specifically included as a dimension to corporate reputation. This respondent expressed the view that whilst most companies inadvertently address each of the possible corporate reputation dimensions whether they are actively doing so or allowing it to passively occur, this particular dimension of reputation is the often missed building block of corporate reputation. If you do not have a plan to save your reputation, should a mishap face the company, all efforts on the other dimensions become irrelevant.

\section{The value of corporate reputation as a competitive advantage}

All directors interviewed believed that corporate reputation was of value to any company, although it was interesting to note that whilst the value was acknowledged, directors had different views on whether corporate reputation offered a competitive advantage. As enunciated by one of the directors:

"our customers go to where the value is, they don't think, okay I am going to go to X company because their reputation is better, Is an excellent reputation better than a good reputation, what's the differentiation?"

This is supported by the view of another director who stated that:

"Competitive advantage is a bit of a tricky subject. It can give you probably a greater disadvantage, if you have a negative."

In contrast, the majority of the respondents saw a competitive advantage that included elements such as return business; increased investor confidence; loyalty of customers and employees; staff retention; new business; 
ability to attract new employees and the ability to weather reputational infringements better, when one has built a good reputation.

\section{Building and managing corporate reputation}

The respondents clearly believed that corporate reputation should be specifically managed in order to derive the perceived advantages. The respondents were not clear that corporate reputation could be managed and, as there was no qualitative measurement in the minds of directors, there was no need to attempt to measure reputation.

The information supplied from the interviewees was varied with regards to the manner in which directors build and manage reputation. Whilst respondents unequivocally acknowledged that directors were the custodians of corporate reputation, the majority of respondents drew a distinction between their roles as custodians and the responsibility of all employees to maintain and protect the reputation of the company. As stated by one respondent:

"I think it's a message that's got to permeate through the organisation and each individual has got to do their bit to making sure that they add up to the reputation of the company. I don't think it can be placed with one person".

Corporate conduct is the overwhelming theme proposed by directors for the building and management of corporate reputation. This is followed by an equal number of responses that can be categorised into stakeholder engagement and the leadership and people element. It is evident that the conduct of the company must be supportive of reputation building and consistency of its actions must be maintained.

Flowing from the dimensions highlighted by the respondents', the culture of the organisation and the importance of its people were highlighted by the following comment made by a respondent:

"If that message does not permeate throughout the company you can have people at the bottom really sabotaging your reputation, irrespective of what the board says. It's like a culture, it's something you have got to instil, that you have got to make sure it exists, that you've got to be punitive and decisive when its transgressed."

\section{Discussion}

\section{Research question 1}

There was a strong sense from the respondents that morals, ethics and values were strong constituents of the definition of corporate reputation. We propose a definition encompassing the findings of both the academic literature and empirical research as follows:

"the sum of the perceptions of a corporation's past actions; current performance; and future prospects that results from the corporation's ability to deliver valued outcomes to multiple stakeholders and ganges a corporation's moral, ethical and financial standing both internally with employees and externally with its stakeholders, in both its competitive and institutional environments" (adapted from Fombrun and Rindova, 1996; Wiedmann and Buxel, 2005; Walker, 2010).

\section{Research question 2}

All of the dimensions mentioned in the literature review, with the exception of innovation, were mentioned by the respondents. In addition, the dimensions can be supplemented by three additional dimensions that were mentioned by the respondents, namely Black economic empowerment in the South African context; corporate culture and corporate ethos. Slight ambiguity was evident between the dimensions of corporate reputation and strategies to build and manage reputation, such as a crisis response management plan. The need for the distinction between the actual dimensions of corporate reputation and ancillary elements are critical in order for the building blocks of corporate reputation to be clearly established and subsequently be built and managed. It is therefore imperative for directors to clearly understand the actual dimensions that constitute corporate reputation, for then only can these dimensions be managed.

\section{Research question 3}

It is evident that corporate reputation is of immense value to a company and is indeed a key intangible asset. The majority of respondents confirmed the presence of a competitive advantage although not as unequivocally as stated in the literature. The intensity of the competitive advantage is not as certain empirically. All of the respondents agreed that a good reputation is a necessary prerequisite for maintaining a social licence to conduct business. There was no precise consensus by the respondents as to the various competitive advantages that could be leveraged from building corporate reputation, however this does not detract from the significant value that was attributed to corporate reputation by all of the respondents.

\section{Research question 4}

Both the literature and the research gathered in context of this study demonstrate support for the role of directors as custodians of corporate reputation. The board of directors together with the chief executive officer are accountable to stakeholders for the reputation of the company and particularly so in light of the King III Report (IOD, 2009). The King III Report (IOD, 2009) has simply formalised corporate reputation as directors seem to have always been aware that they are the ultimate custodians of the company's reputation.

This study has confirmed that the role of the director is that of a custodian of corporate reputation. However if directors are not sufficiently equipped with both an intimate knowledge of the business as well as the tools and dimensions of corporate reputation, directors will not be able to fulfil their roles as the custodians of corporate reputation. Inevitability it will be the company that is prejudiced by not accumulating adequate reputational stock 
and the competitive advantages and value offered by a sound corporate reputation.

\section{Research question 5}

The dimensions of corporate reputation are pivotal to its building and management by providing directors with the levers with which to measure, monitor and implement corporate reputation. Without these dimensions, directors may aimlessly try and build corporate reputation without much success if they do not understand the constituents of corporate reputation. Directors must focus on building the specific dimensions of corporate reputation in order to establish a sound reputation and accumulate reputational capital. Directors must maintain a long term perspective of the strategic decisions they consider and implement to ensure that the company's reputation will not be jeopardized by pursuing a certain course of action, that may bring benefit in the short term but have negative repercussions in the long term.

It is clear, as demonstrated from the interviews, that stakeholders must be engaged. Accordingly, as expressed by the respondents, it is appropriate in attempting to build the company's reputation that stakeholder mapping exercises are undertaken which entails that the company establishes its influence on stakeholders and its stakeholder's influences on the company. This will assist the company in prioritising stakeholder influences and addressing the stakeholder expectations gaps that can be determined by engaging with the relevant stakeholders.

The company should engage in a purposeful media strategy, dealing with the identified dimensions of corporate reputation, to ensure that appropriate communications are being published in public forums and is meaningful to stakeholders. Directors must accordingly address all forms of communication, including the normally staid financial reporting communication, to ensure that stakeholders trust the reporting and disclosures of the company and subsequently builds reputational capital.

Directors clearly expressed the need for all members of the board to possess cross discipline knowledge about the business. In order for directors to build and manage corporate reputation, the disabling consequence of operating in silos must be diminished at board level with a clear goal to ensure that directors are familiar with all aspects of the business, as well as the risks posed by virtue of the operating environments. This knowledge must extend to the company's strategy pertaining to its reputation and the activities being implemented to build and manage the same. If no such strategy exists, directors must question the board on the lack of such a strategy. Directors ought to propose that this board agenda item receive the required focus in order to elevate the standing of the firm and to enable directors to fulfil their role as custodians of corporate reputation.

Actions speak louder than words as demonstrated in the case of reputation building and this was voiced unequivocally by all respondents. Corporate conduct was established empirically, as an important aspect of corporate reputation and surfaced in the literature as a dimension of corporate reputation. This may include investment into corporate social responsibility programs, however it is submitted that corporate behaviour runs to the core of the corporate identity and subsequently to corporate reputation.

Corporations must be seen to be living the ethical conduct it professes, the values that it communicates and upholding the promises it has made to both internal and external stakeholders. Most of the directors were steadfast in their views that corporate behaviour is instrumental in shaping the reputation of the company. It is submitted that policies and procedures may be of assistance in ensuring appropriate corporate behaviour, however the company's management and leadership are instrumental in building and managing corporate reputation through corporate conduct. The leadership of the company must set the tone for the rest of the company and ensure that inappropriate corporate conduct is immediately dealt with and not tolerated within the organisation at any level.

\section{Conclusion}

The purpose of this study was to explore the perspectives of directors as it relates to several key constituents of corporate reputation. Corporate reputation was identified as a key intangible asset of the company that could serve as a basis of competitive advantage if successfully built and managed by directors in their roles as the custodians of a company's reputation. This study has surfaced the dimensions of corporate reputation that provide the levers to build and manage corporate reputation. By demonstrating the value that is associated with corporate reputation and by ascertaining that directors are indeed the appropriate custodians of corporate reputation, there will be better acceptance in introducing and dealing with corporate reputation as a board room agenda item, that is well understood and implemented.

\section{Limitations and suggestions for further research}

As this study was qualitative in nature, the most significant limitation is the inability to generalise the findings emanating from this research. As this research addressed a perceived short-coming in the literature, it is suggested that the findings be quantitatively researched in order to be able to extrapolate the findings, as appropriate.

The following areas for further study are suggested: quantitatively testing the portfolio of corporate reputation dimensions as established within this research; weighting the corporate reputation dimensions in terms of its impact and therefore priority to the business; as the sample was from one target company, the findings may be tested across a sample of different companies or across an industry; and as this research was based on ascertaining the views of only the directors (namely, one stakeholder group), a further study could test the views of multiple stakeholders of one company. 


\section{References}

Alsop, R. 2004. The 18 immutable laws of corporate reputation. New York: Free Press.

Ang, S.H. \& Wight, A. 2009. 'Building intangible resources: The stickiness of reputation', Corporate Reputation Review, 12(1):21-32.

Barnett, M.L., Boyle, E. \& Gardberg, N. A. 2000. 'Towards one vision, one voice: A review essay of the third international conference on corporate reputation, image and competitiveness', Corporate Reputation Review, 3(2):101111 .

Barnett, M.L., Jermier, J.M. \& Lafferty, B.A. 2006. 'Corporate reputation: The definitional landscape', Corporate Reputation Review, 9(1):26-38.

Bryson, J.M. 2004. 'What to do when stakeholders matter? Stakeholder identification analysis techniques', Public Management Review, 6:21-53.

Carroll, C. 2004. 'How the mass media influence perceptions of corporate reputation: Exploring agendasetting effects within business news coverage'. Ph.D. thesis, University of Texas.

Carter, S.M. 2006. 'The interaction of top management group, stakeholder, and situational factors on certain corporate reputation management activities', Journal of Management Studies, 43(5):1145-1176.

Coombs, W.T. 2007. 'Protecting organization reputations during a crisis: The development and application of situation crisis communication theory', Corporate Reputation Review, 10(3):163-176.

Davies, G., Chun, R. \& Da Silva, R.V. 2001. 'The personification metaphor as a measurement approach for corporate reputation', Corporate Reputation Review, 4(2):113-127.

Dowling, G. 2006. 'Reputation risk: It is the board's ultimate responsibility', Journal of Business Strategy, 27(2):59-68.

Fang, L.H. 2005. 'Investment bank reputation and the price and quality of underwriting services', The Journal of Finance, 60(6):2729-2761.

Firestein, P.J. 2006. 'Building and protecting corporate reputation', Strategy \& Leadership, 34(4):25-31.

Fombrun, C.J. 1996. Reputation: Realizing value from the corporate image. Boston: Harvard School Business Press.

Fombrun, C.J. 2007. 'Lists of lists: A compilation of international corporate reputation ratings', Corporate Reputation Review, 10(2):144-153.
Fombrun, C.J. \& Rindova, V.P. 1996. 'Who's tops and who decides? The social construction of corporate reputations', Working Paper, Leonard N. Stern School of Business, New York University.

Fombrun, C.J. \& Rindova, V.P. 2001. 'Fanning the flame: corporate reputations as social constructions of performance'. In Porac, J. \& Ventresca, M. (eds.). Constructing markets and industries. New York: Oxford University Press.

Fombrun, C.J. \& Van Riel, C.B.M. 1997. 'The reputational landscape', Corporate Reputation Review, 1:5-13.

Fombrun, C.J. \& Van Riel, C.B.M. 2004. Fame and fortune: How successful companies build winning reputation. New Jersey: Pearson Education.

Gabbioneta, C., Ravasi, D. \& Mazzola, P. 2007. 'Exploring the drivers of corporate reputation: A study of Italian securities analysts', Corporate Reputation Review, 10(2):99123.

Galliard, G.S \& Louisot, J. 2006. 'Risks to reputation: A global approach', The Geneva Papers on Risk and Insurance-Issues and Practices, 31: 425-445.

Gardberg, N.A. \& Fombrun, C.J. 2006. 'Corporate citizenship: Creating intangible assets across institutional environments', Academy of Management Review, 31(2):329346.

Gibson, D., Gonzales, J.L. \& Castanon, J. 2006. 'The importance of reputation and the role of public relations', Public Relations Quarterly, 51(3):15-18.

Hall, R. 1993. 'A framework linking intangible resources and capabilities to sustainable competitive advantage', Strategic Management Journal, 14:607-618.

Hillenbrand, C. \& Money, K. 2007. 'Corporate responsibility and corporate reputation: Two separate concepts or two sides of the same coins?' Corporate Reputation Review, 10(4):261-277.

Institute of Directors of Southern Africa (IOD). 2009. King III Report on governance for South Africa. Johannesburg: IOD.

Jagt, R. 2005. 'Senior business executives see communication and reputation as a crucial part of their leadership role', Corporate Reputation Review, 8(3):179186.

Kana, S. 2009. Executive guide to King III Report. Johannesburg: PricewaterhouseCoopers publication.

Kiel, G., Nicholson, G. \& Barclay, M. 2005. Board, director and CEO evaluation. Australia: McGraw-Hill.

Kim, J.N., Bach, S.B. \& Clelland, I.J. 2007. 'Symbolic or behavioural management? Corporate reputation in high- 
emission industries', Corporate Reputation Review, 10(2,):77-98.

Larkin, J. 2003. Strategic reputation risk management. New York: Palgrave MacMillan.

Lewellyn, P.G. 2002. 'Corporate reputation: Focusing the zeitgeist', Business and Society, 41(4):446-455.

Mackenzie, C. 2007. 'Boards, incentives and corporate social responsibility: The case for a change in emphasis', Corporate Governance: An International Review, 15(5): 935-943.

Mahon, J.F. 2002. 'Corporate reputation: A research agenda using strategy and stakeholder literature', Business and Society, 41(4):415-445.

Mercer, M. 2004. 'How do investors assess the credibility of management disclosure?' Accounting Horizons, 18(3):185196.

Miles, M.B. \& Huberman, M.A. 1994. Qualitative data analysis: An expanded sourcebook. Thousand Oaks: Sage Publication.

O'Callaghan, T. 2007. 'Disciplining multinational enterprises: The regulatory power of reputational risk', Global Society, 21(1):95-117.

Petkova, A.P., Rindova, V.P. \& Gupta, A.K. 2008. 'How can new ventures build reputation? An exploratory study', Corporate Reputation Review, 11(4): 320-334.

Pruzan, P. 2001, 'Corporate reputation: Image \& identity', Corporate Reputation Review, 4(1):50-64.

Puncheva-Michelotti, P. \& Michelotti, M. 2010. 'The role of stakeholder perspectives in measuring corporate reputation', Marketing Intelligence \& Planning, 28(3): 249-274.

Reichart, J. 2003. 'A theoretical exploration of expectational gaps in the corporate reputation construct', Corporate Reputation Review, 6:58-59.

Roberts, J., McNulty, T. \& Stiles, P. 2005, 'Beyond agency conceptions of the work of the non-executive director: Creating accountability in the boardroom', British Journal of Management, 16(1):5-26.

Walker, K. 2010. 'A systematic review of the corporate reputation literature: Definition, measurement and theory', Corporate Reputation Review, 12(4):357-387.

Wartick, S. 2002. 'Measuring corporate reputation: definition and data', Business and Society, 41(4):371-392.

Wiedmann, K.P. 2002. 'Analyzing the German corporate reputation landscape', Corporate Reputation Review, 4:337353.
Wiedmann, K.P. \& Buxel, H. 2005. 'Corporate reputation management in Germany: Results of an empirical study', Corporate Reputation Review, 8(2):145-163.

Whetten, D.A. \& Mackey, A. 2002. 'A social actor conception of organisational identity and its implications for the study of organisational reputation', Business \& Society, 41(4):393-414.

Zandstra, G. 2002. 'Enron, board governance and moral failings', Corporate Governance, 2(2):16-19. 